\title{
Effects of Scaffolded Voluntary Reading on EFL Students' Reading Comprehension
}

\author{
Agus Sholeh \\ Dr. candidate, Universitas Negeri Malang, \& Lecturer of English Education \\ Department, Universitas Kanjuruhan Malang, Indonesia, sholeh_agus@unikama.ac.id
}

\section{Punaji Setyosari}

Prof., Graduate Program of Educational Technology, Universitas Negeri Malang, Indonesia, punaji.setyosari.fip@um.ac.id

\section{Bambang Yudi Cahyono}

Prof., English Department, Universitas Negeri Malang, Indonesia, bambang.yudi.fs@um.ac.id

\section{Sulthoni}

Dr., Graduate Program of Educational Technology, Universitas Negeri Malang, Indonesia, sulthoni.fip@um.ac.id

This research aimed to find out the effect of Scaffolded Voluntary Reading (SVR) as a special treatment to cope with reading crisis that cannot be solved simply by reading comprehension courses in formal curriculum. Comprehension scaffolding is normally implemented in class as a strategy but in this research, it is transformed into Self-Checking Comprehension Scaffolding (SCCS) to accompany voluntary reading and to scaffold students' comprehension. This research applied quasiexperimental with pre-test post-test control group design that involved 129 Indonesian private university students of English language education. They were divided into two groups: 69 students in the experimental group and 60 students in the control group. The students in the experimental group were treated with SVR provided with SCCS and those in the control group were treated with voluntary reading without SCCS. The data were analyzed using t-test and the result showed that 1) the treatment significantly influenced students' achievement in EFL reading comprehension and 2) SVR promoted the students' self-selected reading, independent reading, and student-centered learning. The finding implies that the students who did SVR with SCCS comprehended better than those without SCCS.

Keywords: voluntary reading, scaffolded voluntary reading, reading comprehension, comprehension scaffolding, self-checking comprehension scaffolding, EFL

Citation: Sholeh, A., Setyosari, P., Cahyono, B. Y., \& Sutlhoni. (2019). Effects of Scaffolded Voluntary Reading on EFL Students' Reading Comprehension. International Journal of Instruction, 12(4), 297-312. https://doi.org/10.29333/iji.2019.12419a 


\section{INTRODUCTION}

The World's Most Literate Nations (WMLN) in 2016 released the rankings of countries with the highest literacy rates in the world. Research conducted by. Miller J. W., President of Central Connecticut State University, New Britain in more than 60 countries in the world revealed that Nordic countries like Finland, Iceland, Denmark, Sweden and Norway occupy the top list in this ranking. While the developed countries in the world such as the United States is ranked 7th, Canada 11th, France 12th, and United Kingdom (UK) 17th. Meanwhile Indonesia is ranked 60th below Thailand (59), Malaysia (53), and Singapore (36) as the country with the highest literacy rating in Southeast Asia (Miller \& McKenna, 2016)

Literacy Crisis in Indonesia especially on reading comprehension, independent reading or reading interest and reading habit cannot be elucidated simply by giving courses offered in the curriculum but it requires activities and strategies that ultimately increase interest and reading habits. Research on reading comprehension is necessary because low mastery of English as a foreign language (EFL) reading is due to several factors, more particularly the learning strategy that is still teacher-centered and content oriented (Jacobs \& Renandya, 2015). Therefore, teachers are advised to apply various strategies that give language exposure and motivation to learners of language (Alshumaimeri, 2011; Widiati \& Cahyono, 2006).

The discussion on learning strategy has been important in both language learning and teaching. Many language teachers rely on their belief that learners with strategic knowledge of language learning become more successful since they can study language efficiently; thus they learn a language more effortlessly (Alharbi, 2015; Heriyawati, Saukah, \& Widiati, 2018; Nosratinia \& Shakeri, 2013; Zarei, Esfandiari, \& Akbari, 2017). Voluntary reading (VR) influences students' comprehension by involving interest and reading habit and they becomes a single factor most strongly associated with reading achievement, more than socio-economic status or any instructional approach (Hiemstra, 2006; Krashen, 2004; Stairs \& Burgos, 2010; Zhang et al., 2015).

VR increases students' interest and reading habit and finally it leads to the increase in the learners' ability in reading, and those who read much demonstrate greater competence in some aspects of literacy and this affects the growth and competence of reading habit and it leads them to have a higher level of education (Kheirzadeh \& Tavakoli, 2012; Stairs \& Burgos, 2010; Zarei, Esfandiari \& Akbari, 2017).

The empirical evidence above shows that voluntary reading have great benefits in increasing students' reading comprehension but we attempted to find out whether this evidence can work well in Indonesia when it is related to the literacy crisis, not only dealing with reading habit and interest but also with the use of interesting and various books. We also paid close attention to the requirements and factors that should be considered to apply VR in Indonesia. Based on Krashen's (Krashen, 1997) recommendations to apply VR we should consider, first, whether learners actually read while reading in school because many children do not really read; they like to read 
interesting reading materials that are provided at school. Second, whether they keep reading too easy material never switch to more challenging reading material.

We adapted and implemented voluntary reading with comprehension scaffolding, shortly called Scaffolded Voluntary Reading (SVR), to overcome the problem of independence, interest, reading habit, and reading comprehension. SVR can be a solution because in SVR students are required to play an active and independent role from asking themselves and answering questions, to plan, and to assess their own learning outcomes (Hiemstra, 2006; Krashen, 1997; Parr \& Maguiness, 2005; Worthy, 1996)

Referring to the background, this study aims to explore the implementation of SVR and its effect on EFL students' reading. In particular, this study addresses the following research questions:

1. How is comprehension scaffolding implemented in voluntary reading?

2. Does Scaffolded Voluntary Reading influence EFL students' reading comprehension?

\section{LITERATURE REVIEW}

One of the language skills students need to master is reading because through reading they can broaden their knowledge about the world and their specialized subjects. Therefore, reading comprehension needs to be ultimate goal in the teaching of reading.

Reading means reading and understanding. A student who says "I can read but I do not understand the meaning" means that he or she does not read, but he or she does only the process of decoding written symbols into spoken language (Urr, 2012). Reading comprehension is also the process of understanding the message in the text related to the knowledge and experience of previous readers and mental representations in the memory of the text (Kintsch, 1980). Reading is essentially a process of building meaning from messages conveyed through written symbols. In the process, the reader integrates or links information, messages in writing with the knowledge or experience of the reader. In the process of reading, readers use a variety of skills including physical and mental skills (Woolley, 2011). Therefore, reading comprehension is an important skill when someone reads to get information about a topic, to be educated, or just read as entertainment. Reading skills are also very important for "EFL learners" (Nosratinia \& Shakeri, 2013).

Nowadays students are required to study more independently so that they do not depend too much on the teacher. Independent study can be done among others by free voluntary reading. Students have more chance to select text or book to read in voluntary reading activity, even they feel free to involve to read with since they do not have to report what they read to teachers directly. This is a strategy to motivate students to read independently and to choose their own books according to their level of independence (Hiemstra, 2006; Krashen, 2016; Parr \& Maguiness, 2005; Ranjbar \& Ghonsooly, 2017). 
We adapted the voluntary reading steps proposed by Harrel and Jordan (2008) as follows: a) identify students' reading level of independence, b) let students select and read texts or books, c) ask the students to discuss the texts or books in groups, d) add motivation over time, and e) assess the students' progress. The VR steps adapted from Harrel and Jordan shown are shown in Figure 1.

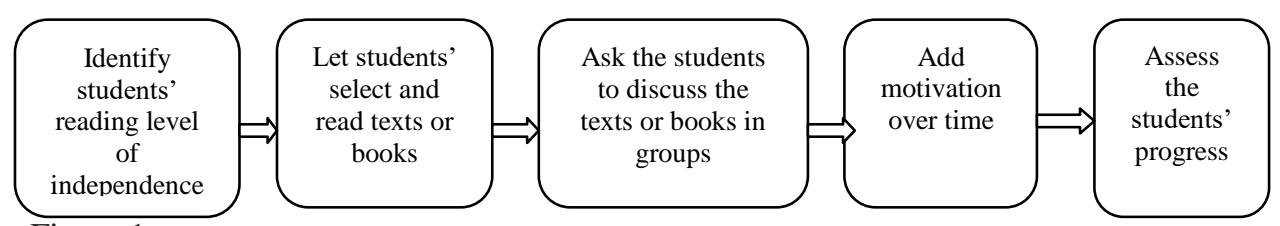

Figure 1

The Voluntary Reading Steps (Harrel \& Jordan, 2008)

The activities undertaken at each stage in VR are as follows: first, we identify reading levels of the students to provide texts or books according to their level; second, we tell students to choose and texts or books, then we give them time to discuss with their friends in group before class discussion, and finally we assess students' progress by observing and recording students' progress whether they have completed reading and understanding the texts (Harrel \& Jordan, 2008).

To help students to read independently and comprehend texts, we provided the VR with Self-Checking Comprehension Scaffolding (SCCS) that is called Scaffolded Voluntary Reading (SVR) (White \& Kim, 2008). Comprehension scaffolding is a process to help students to comprehend texts provided in form of SCCS. There are two main steps involved in comprehension scaffolding: (1) development of lesson plans to guide students in understanding new material, and (2) implementation of plans by assisting the students at every step of the learning process.

Comprehension scaffolding activities was applied in the learning process ranging from pre-reading, during reading and post reading as in the following table (Hiang et al., 2012; Kathleen \& Michael, 2005; Vacca, 2008; White \& Kim, 2008).

Table 1

Comprehension Scaffolding in Reading (Kathleen \& Michael, 2005)

\begin{tabular}{|c|c|c|}
\hline Pre reading & During reading & Post reading \\
\hline 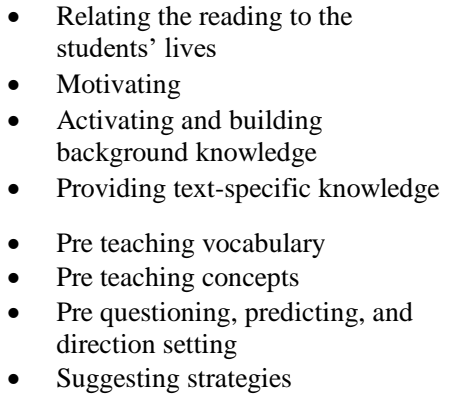 & $\begin{array}{ll}\text { - } & \text { Silent reading } \\
\text { - } & \text { Reading to students } \\
\text { - } & \text { Supported reading } \\
\text { - } & \text { Oral reading by } \\
& \text { students }\end{array}$ & $\begin{array}{ll}\text { - } & \text { Questioning } \\
\text { - } & \text { Discussion } \\
\text { - } & \text { Writing } \\
\text { - } & \text { Drama } \\
\text { - } & \text { Artistic and nonverbal } \\
& \text { activities } \\
\text { - } & \text { Application and outreach } \\
\text { - } & \text { activities } \\
\text { - } & \text { Re teachilding connections }\end{array}$ \\
\hline
\end{tabular}


The comprehension Scaffolding applied in this research was implemented with SCCS which contains statements to help students comprehend text they have chosen. It was given to the students before they read according to part of texts, and this SCCS was developed based on comprehension scaffolding phases of pre reading (introducing title, introducing vocabulary, and inviting for prediction), during reading (activating reading aloud/thinking aloud, and encouraging silent reading) and post reading (motivating questioning/discussion and encouraging for summary-making).

\section{METHOD}

\section{Research Design}

This research is to analyze the difference of EFL students' reading comprehension achievement taught directly with SVR. This quasi experimental research applied pretestposttest control group design. Pretest was used to measure the students' early ability and post-test was for the assessment of reading comprehension after the treatment.

\section{Participants}

The subjects of this study were English Language Education students of Kanjuruhan University of Malang, a private university in East Java, Indonesia who took the Extensive Reading course. Based on the study design, two groups were established: the first group was 69 students in the experimental group who received Scaffolded Voluntary Reading (SVR) introduced by White and Kim (2008) and other 60 students as control group received voluntary reading introduced by Krashen (1997) without comprehension scaffolding. The experimental group was taught by one of the researchers and the control group was taught by the classroom teacher.

\section{Instruments}

An objective test of 30 questions with 4 choices was used to assess students' reading comprehension. The test was developed based on the curriculum and syllabus of Extensive Reading course which included questions to identify reading comprehension.

Questionnaire was distributed to get information about students' responses on the implementation of SVR which consists of 4 statements for Voluntary Reading and 8 statements for comprehension scaffolding with "Yes" or "No".

\section{Data analysis}

Research data was analyzed by using statistical analysis that includes normality test and homogeneity test. The data was described using univariate descriptive data analysis which included average and standard deviation. The t-test was used to compare the of reading comprehension scores from the pre-test and post-test using SVR (scaffolded voluntary reading) and VR without comprehension scaffolding. 


\section{FINDINGS}

\section{Implementation of Comprehension Scaffolding in Voluntary Reading}

The comprehension scaffolding which is transformed into self-checking comprehension scaffolding (SCCS) was used to help students to read independently and comprehend the text they have read. The SCCS is developed on the basis of comprehension scaffolding in reading that can be applied in the learning process ranging from pre-reading, during reading and post reading (Kathleen \& Michael, 2005). The following is the activity of SVR for students who read "Ecotourism" with SCCS (Engelhardt, 2013).

Table 2

Self-Checking Comprehension Scaffolding in pre-reading

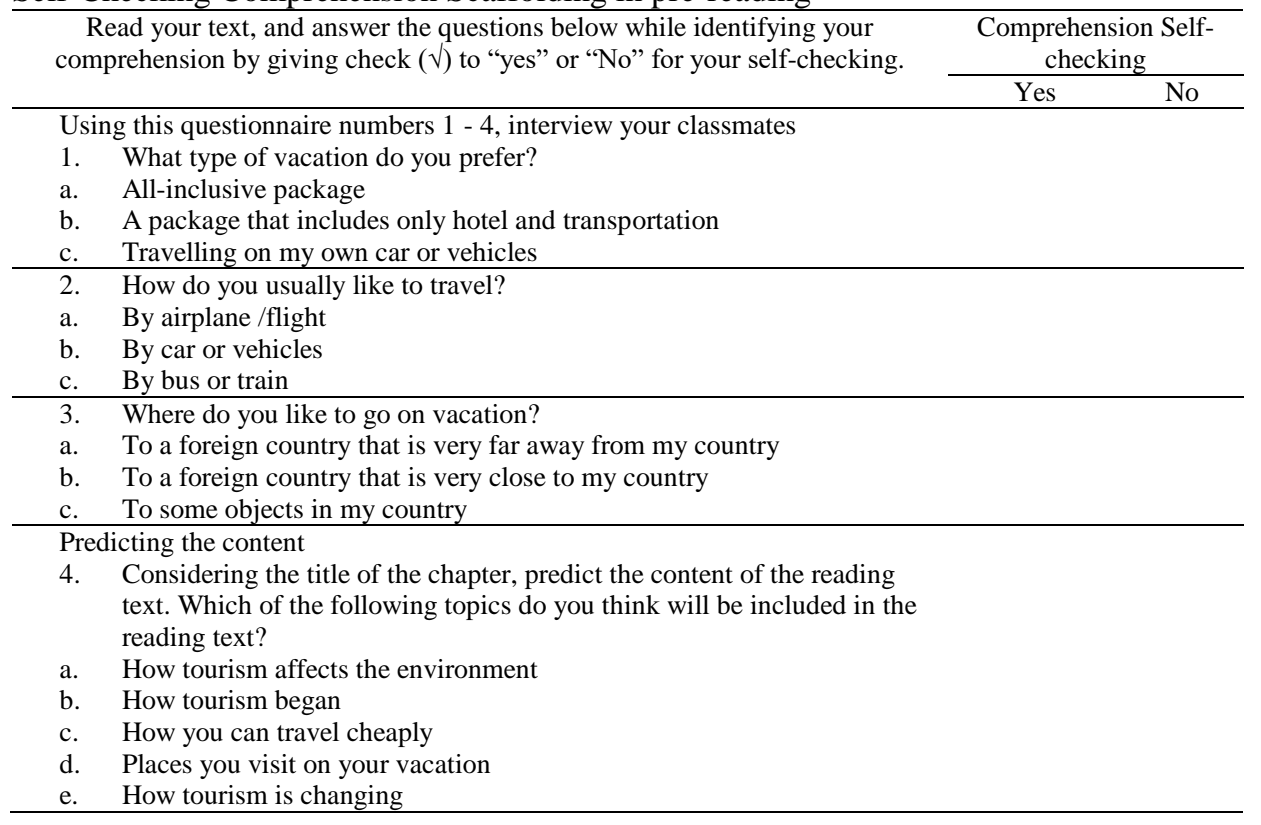

The SCCS for pre-reading helped the students to relate the text to their lives, to activate their background knowledge, to do pre-questioning, and to predict the content of the passage. When they had answered the questions on their own and understood these points they might give check $(\sqrt{ })$ to statement "yes" or "no." These prompts were designed to motivate students to read voluntarily and activated their imagination related to their lives by telling what kind of vacations they prefer, how they like to travel, where they like to go on vacation, and where they like to stay when they are on vacation. They continued to predict what the texts would be about. There are some options for the prediction whether the passage is about the effect of tourism to the environment, when the tourism began, how to ravel cheaply, places to visit, and how the tourism is changing. Students may choose one or more as they predict the topics that would be discussed in the passage. 
Table 3

Self-Checking Comprehension Scaffolding in during reading

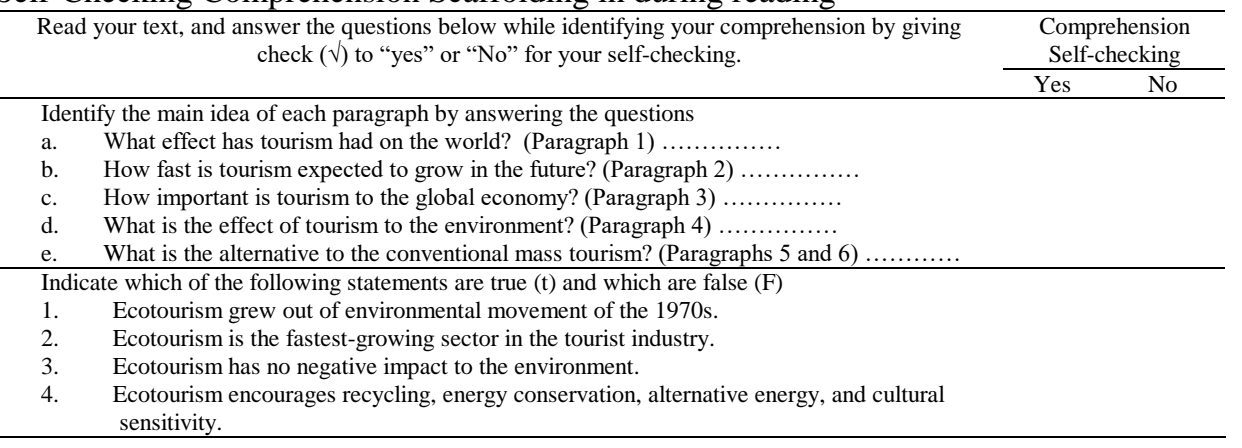

Then SCCS in during reading encouraged students to read silently and to have discussion with friends. This leads students to understand the important components of texts such as the main idea of each paragraph. The comprehension scaffolding leads the students by giving prompts that help students to identify the main idea, such as "what the effect has tourism had on the world?" In this case students may answer that the tourism have made the world smaller and more accessible. Another activity in during reading which explores includes asking the students to identify statements which are true or false according to the texts, such as they should identify whether the statement "ecotourism has no negative impact to the environment" is true or false. When they read the text in detail and understand they can come to the comprehension that larger numbers of ecotourism consume more resources and leave larger impact to the environment and ecotourism spreads to more sensitive corners of the earth, and it could end up defeating its original purposes.

Table 4

Self-Checking Comprehension Scaffolding in post reading.

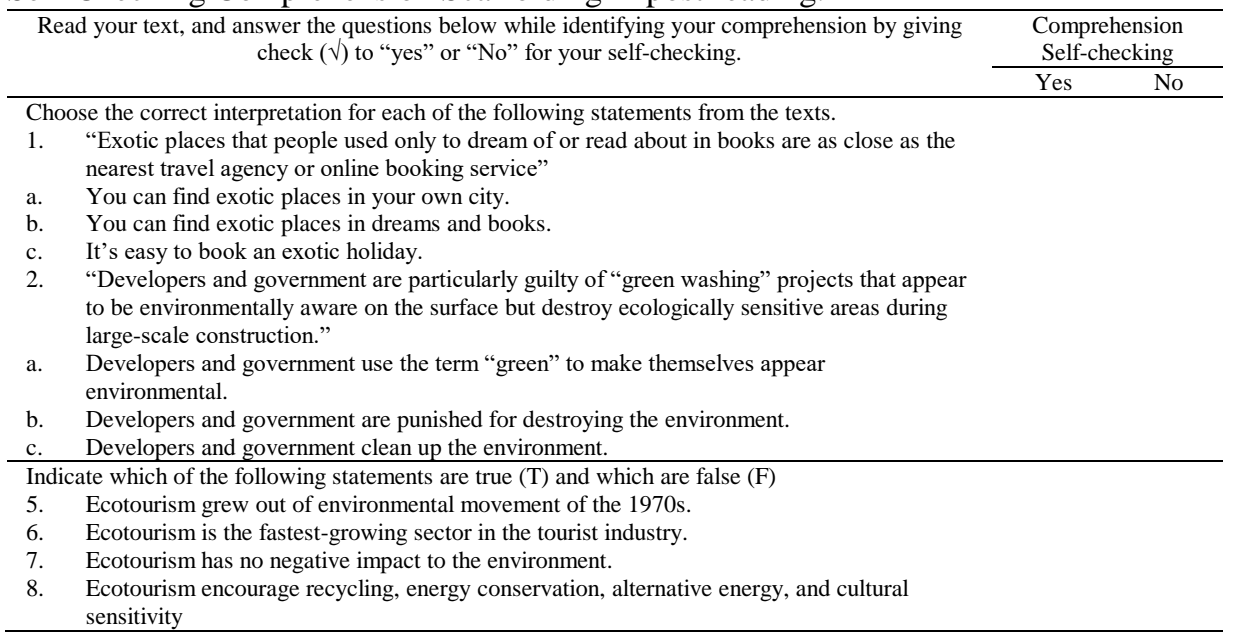


In post reading, students are helped to do inferential comprehension by choosing the correct interpretation of provided statement taken from the text such as whether "Exotic places that people used only to dream of or read about in books are as close as the nearest travel agency or online booking service". When they had understood the statement well, they would interpret that "it's easy to book exotic places". To conclude this activity of SVR with "Ecotourism," students then write their own summary based on the heading statements provided for each paragraph from the reading text

\section{Reading Comprehension Test Scores}

\section{Reliability of test}

The test of reading comprehension tests was conducted on students who had received material such as the material carried out in this study. The number of subjects involved was 60 people. The results of the tests show that:

a. Cronbach's alpha reliability concept understanding test is 0.922

b. The level of difficulty, namely: the items in the moderate category are 21 items (items $1,3,4,5,7,8,9,10,11,12,15.16,18,19,21,23,24,25,26,27$ and 30), items in easy category are 19 items (items $2,6,13,14,17,20,22,28$, and 29), there are no questions that are categorized as difficult.

c. There are enough categories and good categories (minimum difference 0.2)

Table 5

Reliability Statistics

\begin{tabular}{ll}
\hline Cronbach's Alpha & N of Items \\
\hline .816 & 30 \\
\hline
\end{tabular}

The reliability of the instrument is to measure the reliability of the questions of reading comprehension, and the result is 0.816 . This value is sufficient to measure the type of question. These results have met the criteria that reliability (Cronbach's alpha coefficient) of the minimum instrument for measuring learning outcomes is more than 0.816 .

\section{Validity of test}

The following are the results of testing the reliability of the problems that have been carried out by the researcher: 
Table 6

Case Processing Summary

\begin{tabular}{llcc}
\hline Cases & Valid & 60 & 100.0 \\
& Excluded $^{\mathrm{a}}$ & 0 & .0 \\
& Total & 60 & 100.0 \\
\hline
\end{tabular}

a. Listwise deletion based on all variables in the procedure.

Table 5 shows that the questions that are tested on 60 students from a case processing summary are valid.

\section{Test of normality}

Normality testing in this study uses Kolmogorov-Smirnov statistics at a significance level of $5 \%$.

Table 7

Result of Normality Test of Pre-Test

\begin{tabular}{llcccccc}
\hline & & \multicolumn{3}{c}{ Kolmogorov-Smirnov } & \multicolumn{3}{c}{ Shapiro-Wilk } \\
\cline { 3 - 9 } & Groups & Statistic & df & Sig. & Statistic & Df & Sig. \\
\hline $\begin{array}{l}\text { Reading } \\
\begin{array}{l}\text { comprehens } \\
\text { ion }\end{array}\end{array}$ & SVR & .121 & 69 & .077 & .957 & 69 & .077 \\
\cline { 2 - 10 } & VR & .124 & 60 & .079 & .960 & 60 & .121 \\
\hline
\end{tabular}

a. Lilliefors Significance Correction

The results of the data normality test showed the significance (sig.) is greater than 0.05 (sig.> 0.05). Thus, pretest data of reading comprehension of students is normally distributed.

\section{Test of homogeneity}

Homogeneity testing in this study used Levene's Test of Equality of Error Variances to test the variance homogeneity and Box's Test of Equality of Covariance Matrices to test the homogeneity of the covariance matrix, at a significance level of $5 \%$.

Table 8

Result of Homogeneity test of Reading Comprehension

\begin{tabular}{lcccc}
\hline \multicolumn{5}{c}{ Levene's Test of Equality of Error Variances } \\
\hline Reading comprehension & F & df1 & df2 & Sig. \\
\hline
\end{tabular}

Tests the null hypothesis that the error variance of the dependent variable is equal across groups.

The results in Table 8 of the variance homogeneity test of reading comprehension shows significance (sig.) is greater than 0.05 . Thus, it can be concluded that the test data come from homogeneous groups.

Table 9 shows that the results of the homogeneity of the covariance matrix test from literal and inferential understanding test data show Box's M number 27.867 with significance (sig.) is smaller than $0.05(0.002<0.05)$ so that it indicates the covariance matrix of the dependent variable / dependent variable is not the same. Although the homogeneity of the covariance matrix is not fulfilled, the homogeneity of the variance 
can be fulfilled (one requirement can be fulfilled by the data), then the research process can be continued.

Table 9

Homogeneity Test Covariance Matrices Data of Reading Comprehension

\begin{tabular}{ll}
\hline Box's Test of Equality of Covariance Matrices $^{\mathrm{a}}$ & \\
\hline Box's M & 27.867 \\
F & 2.969 \\
df1 & 9 \\
df2 & 76902.761 \\
Sig. & .002 \\
\hline
\end{tabular}

The results of the comprehension test are shown in Table 8. As can be seen, students scored higher when they got comprehension scaffolding than those who did not get it. A $\mathrm{T}$ test analysis with treatment and EFL reading comprehension as independent variable show that the overall effect of treatment was significant, $(1,92)=22,49, p<0.1$. The SVR significantly affected students' EFL reading comprehension.

Table 10

Comparison Scores of Pre-Test and Post-Test of the Experimental and Control Groups

\begin{tabular}{lll}
\hline & Comparison score of reading comprehension \\
\hline & Voluntary reading with & Voluntary reading without \\
& comprehension scaffolding & comprehension scaffolding \\
\hline Pre test & 76 & 74 \\
Post test & 87 & 78 \\
Average across the two tests & 81.5 & 76 \\
\hline
\end{tabular}

Table 10 reveals that the EFL students' reading comprehension has different average scores in that the students with comprehension scaffolding had better average score (81.5) than those without comprehension scaffolding (76). They started from similar ability with scores of 76 and 74 in the pre-test, respectively. The score of the experimental group increases significantly from 76 to 87 and the control group gain score 74 in pre-test and increase their score 78 in the post-test. The close look on EFL reading comprehension of students of the experimental group, the students' mean scores of the pre-test and post-test who get the SCCS can be seen in Table 6. To measure the changes students attained through the treatment, a paired samples t-test was calculated for their pre-test and post-test results.

Table 11

The Comparison of the Pre-Test and Post-Test Score of the Experimental Group

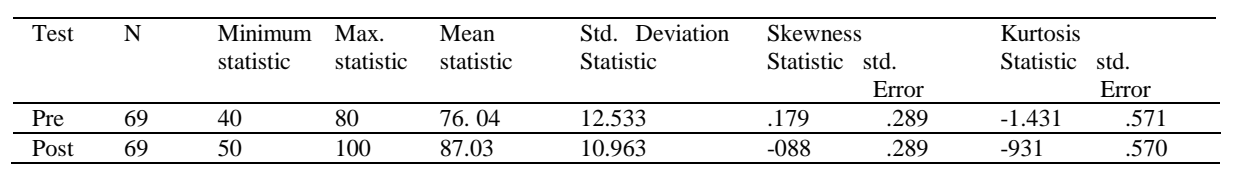

The SVR treatment has improved students' reading comprehension score from 76.04 in the pre-test to 87.03 in the post-test. The increase in reading scores might have been gained due to the treatment, which involved teacher and student engagement. Strong significant differences were exhibited in the students' post-test; and this supports the 
claim that employing SVR improved reading comprehension skill. The results disclosed that there were significant improvements in the students' reading comprehension scores over time. The finding is consistent with White and Kim (2008) which shows that the students in the treatment with Scaffolded Free Voluntary Reading demonstrated improvement on reading comprehension.

\section{Implementation of Scaffolded Voluntary Reading}

Questionnaire number 1 to 4 explored students' responses on the implementation of SVR focusing on the students' participation in SVR. The result reveals that the students participated in FVR, beginning from choosing books or texts they like (100\%), being given information on the implementation of Scaffolded Voluntary Reading and the advantages of this activity for their reading comprehension (100\%), having the opportunity to discuss the books or texts that they have read with their classmates before the lesson (97.10\%), and being given motivation to read over the time $(98.55 \%)$.

Table 12

Students' Responses on Scaffolded Voluntary Reading (N=69)

\begin{tabular}{lllll}
\hline NO & Scaffolded Voluntary Reading & \multicolumn{2}{c}{ Students' Response } \\
\cline { 3 - 5 } & & Item & $\begin{array}{c}\text { Number of } \\
\text { answers }\end{array}$ \\
\hline \multicolumn{2}{l}{ Voluntary Reading } & & & 100 \\
\hline 1 & Opportunity to choose books or texts & Yes & 69 & - \\
& & No & - & 100 \\
\hline 2 & Information of Scaffolded FVR & Total & 69 & 100 \\
& & Yes & 69 & - \\
\hline 3 & Opportunity to discuss books or texts before lesson & No & - & 97.10 \\
& & Total & 69 & 2.89 \\
& & Yes & 67 & 100 \\
\hline 4 & Motivation to read & Total & 69 & 98.55 \\
& & Yes & 68 & 1.44 \\
& & No & 1 & 100 \\
\hline
\end{tabular}

\section{Implementation of Self-Checking Comprehension Scaffolding (SCCS)}

Questionnaires number 5 to 12 display students' responses on the implementation of SVR focusing on the implementation of self-checking comprehension scaffolding (items numbers 5-12).

Table 13

Students' Responses on the Implementation of Self-Checking Comprehension Scaffolding (N=69)

\begin{tabular}{cclll}
\hline \multicolumn{2}{l}{ Comprehension Scaffolding (CS) } & & & \\
\hline 5 & Relating the reading to students' lives & Yes & 67 & 97.10 \\
& & No & 2 & 2.89 \\
& & Total & 69 & 100 \\
\hline 6 & Activating and building background knowledge & Yes & 66 & 95.65 \\
& & No & 3 & 4.34 \\
& & Total & 69 & 100 \\
\hline 7 & Pre-questioning about the content & Yes & 67 & 97.10 \\
& & No & 2 & 2.89 \\
& & Total & 69 & 100 \\
\hline
\end{tabular}

International Journal of Instruction, October $2019 \bullet$ Vol.12, No.4 
Table 13 shows the students' responses on SCCS on their scaffolded free voluntary reading. It indicates that SCCS helped them introduce and discuss the title by relating the texts to their lives $(97.10 \%)$. The students were also highly encouraged to activate and build their background knowledge related to the topic in pre-reading $(95.65 \%)$. Moreover, SCCS helped them understand the content through pre-questioning $(97.10 \%)$ and predicting $(95.65 \%)$ activities. Then, SCCS activated their reading/thinking aloud $(100 \%)$ and involved the students in questioning and discussion of the content of the text $(98,5 \%)$. Finally, the students were also made active through activities in summarizing and building connections to their experience or life (100\%).

\section{DISCUSSION}

\section{Implementation of SVR}

Students' positive responses to the questionnaires on SVR showed that they enjoyed reading, liked to have discussion, and liked to share what they have read. Thus, the substantial merit of this study was that the students increased their reading comprehension as a result of Scaffolded Voluntary Reading.

Students' responses on the treatment made clear some evidence about the possible reasons that the scaffolded reading comprehension led to the improvement of students' reading comprehension scores. The treatment has created conducive situation to the students to voluntarily read their texts and to stay engaged in cooperation on the reading tasks with their classmates through discussion. As the result, the role of teacher was replaced by students' responsibility by checking their own understanding because students were also involved in activities in pairs, in groups, on students' supports, feedback and independent reading by checking their SCCS (Ardith, 2006; Atta \& Salem, 2017; White \& Kim, 2008).

One of the important factors of voluntary reading that increases EFL students' reading comprehension is the freedom in choosing their preferred texts; this increases the enjoyment of reading since students choose the material based on their preferences in case of topic and types of texts and choose the material suitable to their reading level. They may drop books or materials they are not interested in and the freedom decreases the barriers of reading. A similar important part of voluntary reading is the opportunity to discuss books and motivation to read that provide the students with the same opportunity to share what they have read and complete their understanding on texts (Parr \& Maguiness, 2005; Strommen \& Mates, 2004; Susan La, 2004; Worthy, 1996). Scaffolded voluntary reading also promotes students' improve students' reading fluency and comprehension (Enyew, Yigzaw, \& Muche, 2015), students' reading habit (Hughes, Sandra, \& Rodge, 2007), more students centred learning (Jacobs \& Renandya, 2015) more self-selected reading (Sanden, 2014), and more independent reading (Stairs \& Burgos, 2010). 


\section{The Result of the Comparison Scores of Pre-Test and Post-Test}

The interpretation of the finding can be based on the effects of SVR on EFL students' reading comprehension that is derived from the pre-test and post-test scores. The students in the two groups were given the tests which had the same in time allotment, length of paragraphs, contents, question types, and number of questions administered to check whether or not SVR brought improvements on EFL students' reading comprehension. The analysis of pre-test and post-test scores shows that there is a significant difference in the EFL students' reading comprehension scores. Analyses of students' responses during each lesson also indicated that students have demonstrated gradual and steady improvement in their reading comprehension.

The treatment has increased EFL students' reading comprehension scores from 76 into 87. The increase in reading scores might have been caused by the treatment. Strong significant differences were exhibited in the students' post-test of reading comprehension; and this supports the claim that employing SVR can improve reading comprehension skills. The results revealed that there were significant improvements in the students' reading comprehension scores over time.

This research finding is consistent with some previous studies which highlighted the use of SVR strategy that has increased reading comprehension skill of the students. This research also shows that when a teacher creates reading activities that enable reading engagement to be continuous and pays close attention to reading preference, their EFL students' reading comprehension increases (Hughes et al., 2007; Ogbonna \& Eze, 2015; Watjatrakul, 2013; White \& Kim, 2008).

\section{CONCLUSION}

So far research on SVR was rarely done, especially one which applied SCCS. The findings of the present study indicated that the students' reading comprehension was improved by using SVR. Therefore, it was concluded that the Scaffolded free voluntary reading that is transformed into Self-Checking Comprehension Scaffolding (SCCS) is effective for the development of the students' reading comprehension. This is because students are free to choose texts based on their preferences in terms of topic and types of texts and choose the material suitable to their reading level. This decreases the barriers of reading as they may drop books or texts that they are not interested in. They also have the opportunity to discuss books and get motivation to read. In addition, they have the same opportunity to share what they have read and complete their understanding of texts.

It is necessary for English reading teachers to use Scaffolded Voluntary Reading; therefore, we suggest English reading teachers to apply it in their reading classes. Teachers may provide comprehension scaffolding for students to help them understand texts better that finally students to read texts voluntarily to develop their reading comprehension. Finally, further research may focus on more extended treatment period and different school levels. The research needs to include other data gathering instruments with bigger sample size. Eventually, there should be training on the 
application of SVR for the English language teachers, students and school leaders to make the reading activity more engaging and attractive to students so that students become more responsible, independent and autonomous readers.

\section{ACKNOWLEDGEMENTS}

This research was supported by the Government of the Republic of Indonesia through the Excellence Scholarship for Indonesian Lecturers for In-house Education (Beasiswa Unggulan Dosen Indonesia Dalam Negeri) from the General Directorate of Higher Education.

\section{REFERENCES}

Alharbi, M. A. (2015). Reading strategies, learning styles and reading comprehension : A Correlation Study. Journal of Language Teaching and Research, 6(6), 1257-1268. https://doi.org/10.17507/jltr.0606.13.

Alshumaimeri, Y. (2011). The effects of reading method on the comprehension performance of Saudi EFL students. International Conference on EducationInternational Electronic Journal of Elementary Education, 4(1), 185-195.

Ardith, D. (2006). Scaffolding beginning readers: Micro and macro cues teachers use during student oral reading. The Reading Teacher, 59(5), 450-459. https://doi.org/10.1598/RT.59.5.4.

Atta, A., \& Salem, S. M. (2017). Scaffolding reading comprehension skills. English Language Teaching, 10(1), 97-111. https://doi.org/10.5539/elt.v10n1p97

Engelhardt, D. (2013). Advanced english reading and comprehension. New York: Mc Graw Hill Education.

Enyew, C., Yigzaw, A., \& Muche, M. (2015). Effects of teacher scaffolding on students ' oral reading fluency. Science, Technology and Arts Research Journal, 4(4), 200-207.

Harrel, \& Jordan. (2008). 50 strategies for teaching english language learners. New Jersey: Pearson, Merril Prentice Hall.

Heriyawati, D. F., Saukah, A., \& Widiati, U. (2018). Working memory capacity, content familiarity, and university EFL students' reading comprehension. Indonesian Journal Of Applied Linguistics 8(1), 21-27. https://doi.org/10.17509/ijal.v8i1.11458

Hiang, T. C., Pandian, A., Abdul, S., Mohamed, M., Ahmad, K., \& Ali, A. (2012). Teaching reading to struggling learners. International Journal of Arts \& Sciences, 5(5), 477-488.

Hiemstra, R. (2006). Self-directed learning. The International Encyclopedia of Education, (1994), 1-11. https://doi.org/10.1016/j.resuscitation.2011.01.003

Hughes, H., Sandra, \& Rodge, P. (2007). The leisure reading habits of urban adolescents. Journal of Adolescent \& Adult Literacy, 51(1), 22-33. https://doi.org/10.1598/JAAL.51.1.3. 
Jacobs, G. M., \& Renandya, W. A. (2015). Making extensive reading even more centered. Indonesian Journal of Applied Linguistics, 4(2), 102-112.

Kathleen, F., \& Michael, F. (2005). Scaffolding students' comprehension of text. The Reading Teacher, 58(6), 570-580. https://doi.org/10.1598/RT.58.6.6.

Kheirzadeh, S., \& Tavakoli, E. (2012). The causes of reading difficulty: The perception of Iranian EFL post-graduate and under-graduate students. Journal of Language Teaching and Research, 3(1), 147-152. https://doi.org/10.4304/jltr.3.1.147-152

Kintsch. (1980). Learning from text, levels of comprehension, or: Why anyone would read a story anyway. Poetics. 9(1-3), 87-98. https://doi.org/10.1016/0304$422 \mathrm{X}(80) 90013-3$.

Krashen, S. (1997). Free voluntary reading : It works for first language, second language and foreign language acquisition. Mextesol Journal, 20(3), 11-18.

Krashen, S. (2004). Free voluntary reading: New research, application and controversies. Paper presented at the RELC Conference, Singapore.

Krashen, S. (2016). The researcher' s perspective the pu rpose of education, free voluntary reading, and dealing with the impact of poverty. School Libraries Worldwide, 22(1), 1-7.

Miller, J., \& McKenna, M. (2016). World's most literate nations. Routledge

Nosratinia, M., \& Shakeri, H. (2013). Does reading strategy use predict and correlate with reading achievement of EFL learners? International Journal of Research Studies in Language Learning, 2(2), 299-312. https://doi.org/10.5861/ijrsll.2012.118.

Ogbonna, J., \& Eze, J. U. (2015). Reviving the reading culture: School library programmes in promoting voluntary reading amongst students: The case of Imo State, Nigeria. Library Philosophy and Practice, 2015(1). Retrieved from http://www.scopus.com/inward/record.url?eid=2-s2.084940947930\&partnerID=tZOtx3y1.

Parr, J. M., \& Maguiness, C. (2005). Removing the silent from SSR: Voluntary reading as social practice. Journal of Adolescent \& Adult Literacy, 49(2), 98-107. https://doi.org/10.1598/JAAL.49.2.2.

Ranjbar, N., \& Ghonsooly, B. (2017). Peer scaffolding behaviors emerging in revising a written task : A microgenetic analysis. Iranian Journal of Language Teaching Research, 5(2), 75-90.

Sanden, S. (2014). Out of the shadow of SSR: Real teachers' classroom independent. Language Arts, 91(3), 161-175.

Stairs, A. J., \& Burgos, S. S. (2010). The Power of independent, self-selected reading in the middle grades. Middle School Journal, 4l(3), 41-48. Retrieved from http://search.proquest.com/docview/217434763?accountid=12768. 
Strommen, L. T., \& Mates, B. F. (2004). Learning to love reading: Interviews with older children and teens. International Reading Association, 48(3), 188-200. https://doi.org/10.1598/JAAL.48.3.1.

Susan La. M. (2004). Free voluntary reading and the role of the teacher librarian. International Association of School Librarianship, 171. Retrieved from http://proquest.umi.com/pqdweb?did=1312219791\&Fmt=7\&clientId=18803\&RQT=30 9\&VName=PQD

Urr, P. (2012). A Completely revised and updated edition of a course in language teaching. Cambridge University Press.

Vacca, J. S. (2008). Using scaffolding techniques to teach a social studies lesson about Buddha to sixth graders. Journal of Adolescent \& Adult Literacy, 51(8), 652-658. https://doi.org/10.1598/JAAL.51.8.4.

Watjatrakul, B. (2013). Intention to use a free voluntary service. Journal of Systems and Information Technology, 15(2), 202-220. https://doi.org/10.1108/13287261311328903.

White, T. G., \& Kim, J. S. (2008). Teacher and parent scaffolding of voluntary summer reading. The Reading Teacher, 62(2), 116-125. https://doi.org/10.1598/rt.62.2.3.

Widiati, U., \& Cahyono, B. Y. (2006). The teaching of EFL reading in the Indonesia context: The state of the art. TEFLIN Journal, 17(1), 36-58. https://doi.org/10.15639/TEFLINJOURNAL.V19I1/1-17.

Woolley, G. (2011). Reading comprehension: Assisting children with learning difficulties. Sprniger. https://doi.org/10.1007/978-94-007-1174-7

Worthy, J. (1996). Removing barriers to voluntary reading for reluctant readers: The role of school and classroom libraries. Language Arts, 73(7), 483-492.

Zarei, A. A., Esfandiari, R., \& Akbari, A. (2017). Self-regulated learning strategies as predictors of reading comprehension. English Language Teaching, 3(2), 29-42.

Zhang, Y., Wang, T., Huang, P., Li, D., Qiu, J., \& Shen, T. (2015). Free language selection in the bilingual brain: An event-related fMRI Study. Scientific Reports 5, 11704. https://doi.org/10.1038/srep11704. 